\title{
Accelerating Financial Inclusion for Sustainable Development in Nigeria
}

\author{
Muftau Adesina Abayomi* \\ *Department of Economics, School of Management Technology \\ Federal University of Technology, P.M.B. 704 Akure, Nigeria \\ Oluyemi Philip Ologunwa \\ Department of Economics, School of Management Technology \\ Federal University of Technology, P.M.B. 704 Akure, Nigeria
}

\begin{abstract}
Financial exclusion constitutes a major sustainable development challenge in many developing countries such as Nigeria. This paper examines the financial inclusion efforts in Nigeria, the implications of strong financial inclusion for sustainable development, and the challenges militating against financial inclusion in Nigeria. The paper also discusses the roles of rural banking scheme, Nigeria Deposit Insurance Corporation, and various types of banks as well as the non-interest banking policy and alternative banking channels in financial inclusion. The paper suggests that a strong financial inclusion of the hitherto inadvertently financially excluded and the poor segments of the society would increase economic activities, employment, consumption, government expenditure as well as economic growth and sustainable development. It also identifies the challenges militating financial inclusion in Nigeria to include; low financial literacy, cumbersome banking documentation and minimum operating balance requirements, inadequate and uneven distribution of bank branches and alternative banking channels, low uptime and malfunctioning of e-channels, growing poverty incidence, and high unemployment rate, among others. The paper recommends the re-introduction of rural banking scheme, public enlightenment, minimization of banking documentation and minimum operating balance, increased deployment of alternative banking channels, and stiffer penalty against corruption, among others. A strict implementation of the suggested recommendations would accelerate financial inclusion and ensure sustainable development in Nigeria.
\end{abstract}

Keywords: Financial inclusion, Financial exclusion, Sustainable Development, Nigeria

DOI: $10.7176 /$ RJFA/12-16-05

Publication date:August $31^{\text {st }} 2021$

\subsection{Introduction}

The debate on financial inclusion has been gaining momentum among policy makers, researchers and development finance organizations, especially in developing countries. This is partly because a large number of people have been financially excluded, and have consequently slipped into the abyss of poverty. According to the Centre for Financial Inclusion [CFI] (2010), financial inclusion is a state in which all who can use them have access to a full suite of quality financial services provided at affordable prices, in a convenient manner, and with dignity for the clients. It is a state where financial services are delivered by a range of providers, most of them private sector, and reach everyone who can use them, including the poor, disabled, rural, and other excluded populations.

Financial exclusion constitutes a sustainable development challenge to developing countries. While pervasive financial inclusion has remained a global challenge with as much as $54 \%$ of adults worldwide being financially excluded, some developing countries have as much as $70 \%$ financial exclusion levels (Kama \& Adigun, 2013). Although the global pursuit of financial inclusion as a vehicle for economic development had a positive effect in Nigeria, according to the Central Bank of Nigeria [CBN] (2018), the exclusion rate reduced from $53.0 \%$ in 2008 to $46.3 \%$ in 2010 , and the latter statistic is still considered to be on the high side. The Enhancing Financial Innovation and Access [EFInA] (2008) also notes that majority of Nigeria's population (or $61.9 \%$ ) live in rural areas accessing largely informal financial services. The Non-Governmental Organization also opines that about 50 million people do not have accounts at a formal financial institution, while almost 9.4 million (or 10\%) rely solely on informal finance. Lack of access to formal financial services limits their ability to climb out of poverty, mitigate risks and participate in productive economic activities.

The importance of financial inclusion stems from the promise it holds as a tool for development, particularly in the areas of poverty reduction, employment generation, wealth creation and improving welfare and general standard of living $(\mathrm{CBN}, 2018)$. Although there has been a remarkable drop in the proportion of the global population living below the extreme poverty line in the recent time, this statistic still stood at $13 \%$ as at 2012, which is considered too high. As at the same year in Sub-Saharan Africa, poverty remains widespread with more than $40 \%$ of people living on less than 1.90 US dollars a day (United Nations, 2016). According to the National Bureau of Statistics [NBS] (2012), the proportion of the population living below the poverty line (that 
is, poverty incidence) in Nigeria increased from $27 \%$ in 1980 to $69 \%$ in 2010 and about $71.5 \%$ in 2011.

According to Seers (1969), development can be described as a process whereby poverty, unemployment and inequality in a country consistently and jointly reduce over a long period of time. On the other hand, the World Commission on Environment and Development, otherwise known as the Brundtland Commission (1997) defines sustainable development as the kind of development that meets the needs of the present generation without compromising the ability of future generations to meet their own needs.

Therefore, the objectives of this paper are: to examine the financial inclusion efforts in Nigeria, the implications of strong financial inclusion for sustainable development in Nigeria, and the challenges militating against financial inclusion in Nigeria. The rest of the paper is organized as follows: Section two deals with the review of literature while section three examines the financial inclusion efforts, and implications of strong financial inclusion for sustainable development in Nigeria. Section four discusses the challenges militating against financial inclusion in Nigeria while conclusion and recommendations for accelerating financial inclusion are covered in section five.

\subsection{Literature Review}

Sanusi (2011) attributes the rise in poverty level in Nigeria to the challenges of financial exclusion. According to him, achieving optimal level of financial inclusion in Nigeria means empowering about $70 \%$ of the population living below poverty line, and this will boost growth and development. According to Plymouth City Council [PCC] (2009), financial inclusion describes a process or situation where all members of an economy do not have difficulty in opening bank account; can afford to access credit and can conveniently and consistently use financial system products and facilities without difficulty. Mohan (2006) describes financial exclusion as lack of access by certain segments of the society to appropriate low cost, fair and safe financial products and services from mainstream providers. Access to financial services allows the poor to save money in formal financial institutions safely, rather than under their pillows, beds and pits thereby helping them mitigate the risks of theft and loss.

United Kingdom was one of the first countries to realize the importance of financial inclusion; it published its financial inclusion strategy in 2004 and launched its task force in February 2005 to monitor and report progress on financial inclusion (Kama \& Adigun, 2013). Also, legislations promulgated in Belgium, France and Sweden recognized the right to open account and so prevent banks from refusing to open accounts for intending customers (CGAP, World Bank, 2010). The Bank further notes that while the high income Organization for Economic Cooperation and Development (OECD) countries have as low as $8 \%$, the exclusion rate ranges from $49 \%$ in Central Asia and Eastern Europe to 58\% in South Asia and 65\% in Latin America.

According to Ardic, Heimann and Nataliya (2011), 56\% of adults in the world do not have access to formal financial services while $64 \%$ of adults in developing countries are unbanked. In Brazil, financial inclusion is today considered as a right of all citizens to social inclusion, better quality of life and a tool for strengthening the economic capacity and capabilities of the poor in a nation (Banco Central do Brazil, 2010). The inclusion of the poor segment of the society would generate economic activities, cause growth in national output and eventually reduce poverty (Sanusi, 2011).

According to EFInA (2016), the informally served make up 9.4 million (or 9.8\%) of the Nigerian Adult population of 96.4 million; 7.8 million (or $83.2 \%$ ) are based in rural areas, 6 million (or 55\%) are female, 5.1 million (or 54\%) are under 35 years, 6.2 million (or 66\%) earn less than N18,000 monthly while 4.9 million (or $52.5 \%$ ) own a mobile phone. Financial inclusion requires that attention is given to human and institutional issues, such as quality of access, affordability of products, provider sustainability and outreach to the most excluded populations (Kama \& Adigun, 2013). They argue that the consequence of financial exclusion is the minimization of the scale of economic activities that can be financed and hence, limiting the potentials for higher economic growth.

\subsection{Financial Inclusion Efforts and Implications for Sustainable Development in Nigeria}

The section is organized into three subsections as follows:

\subsection{Financial Inclusion Efforts in Nigeria}

Some of the financial inclusion efforts that have been implemented or currently being adopted in Nigeria include the following:

\section{Rural Banking Scheme}

In 1977, the CBN introduced the Rural Banking Scheme designed to inculcate banking habits among the rural dwellers. During the first Phase which spanned 1977-1980, a total of 200 branches were allocated to the existing 20 Banks in Nigeria. As at $31^{\text {st }}$ December, 1980, a total of 194 branches (or 97\%) was achieved, although 200 branches were eventually opened as at $31^{\text {st }}$ December, 1982. During the second phase (1980-1983), a total of 181 branches (or 68\%) out of 266 branches allocated were opened as at $31^{\text {st }}$ December, 1983 from the existing 20 
Banks operating in Nigeria (CBN Annual Reports and Statements of Accounts 1981-1983).

Nigeria Deposit Insurance Corporation

Established in 1989, the Nigeria Deposit Insurance Corporation (NDIC) is an agency of the Federal Government of Nigeria which operates independently. Its main objective is to protect depositors and guarantee payment of insured funds in the event of failure of insured institutions (CBN, 2017). This would encourage the hitherto unbanked segment of the population to open accounts with deposit money banks when they know that their deposits are protected.

Deposit Money Banks

Deposit Money Banks are otherwise known as Commercial Banks. The functions of Deposit Money Banks include: mobilization of deposits from the surplus sector and channeling same to the deficit sector, implementation of standing orders, and provision of safe-keeping facilities on valuable items (e.g. certificates, and other sensitive items) to customers (CBN, 2017).

Bank of Industry

The Bank of Industry (BOI) was established in 2001 following a reconstruction of the Nigerian Industrial Development Bank (NIDB) Limited, which was established in 1964. The functions of the BOI include: provision of medium and long term finance for the public and private sectors; identification of investment bottlenecks in the Nigerian economy thereby helping to determine investment priorities; and provision of financial, technical and managerial advice and assistance to indigenous enterprises in Nigeria, among others (CBN, 2017).

Nigerian Export-Import Bank

The Nigerian Export-Import Bank (NEXIM) was established by Act 38 of 1991 as an Export Credit Agency (ECA). The Bank replaced the Nigerian Export Credit Guarantee and Insurance Corporation earlier set up under Act 15 of 1988. The statutory functions of the bank include the provision of export credit guarantee and export credit insurance facilities to its clients as well as the provision of credits in local currency to its clients in support of exports, among others (CBN, 2017). Thus, the NEXIM Bank enhances clients' access to credits and encourages the hitherto unbanked potential exporters to open accounts with the bank.

\section{Bank of Agriculture}

The Bank of Agriculture (BOA) was incorporated as Nigerian Agricultural Bank (NAB) in 1973 and in 1978, the name was changed to Nigerian Agricultural and Cooperative Bank (NACB). In 2000, it was merged with the People's Bank of Nigeria (PBN) and took over the risk assets of Family Economic Advancement Programme (FEAP) to become the Nigerian Agricultural Cooperative and Rural Development Bank Limited (NACRDB). The functions of the Bank of Agriculture include: provision of credit to support all activities in the agricultural value chain; provision of non-agricultural micro credit to the poor segment of the society comprising rural artisans, petty traders and inculcation of banking habits at the grass-roots of the Nigerian society, among others (CBN, 2017).

Primary Mortgage Institutions (PMI)

A Primary Mortgage Institution (PMI) refers to any company that is licensed to provide mortgage service in Nigeria (CBN, 2017). The functions of PMIs in Nigeria include: granting of loans or advances to any person for the building, improvement or extension of a dwelling/commercial house; granting of loans and advances to any person for the purchase or construction of a dwelling/commercial house; and accepting savings and deposits from the general public and paying interest thereon, among others.

\section{Microfinance Banks (MFB)}

Microfinance Bank is a financial institution that collects deposits, grants loans, renders insurance and fund transfer services as well as non-ancillary products targeted at low-income clients. Three features distinguish microfinance from other formal financial products: smallness of loans and savings, absence or reduced emphasis on collateral, and simplicity of operations (CBN, 2011b). The functions of the Microfinance Banks include: provision of timely, diversified, affordable, and dependable financial services to the economically active poor; creation of employment opportunities and increase in the productivity and household income of the active poor thereby enhancing their standard of living; promotion of synergy and mainstreaming of the informal

\section{Other Relevant Financial Inclusion Initiatives}

Some other relevant financial inclusion initiatives embarked upon by the CBN include the non-interest Banking policy which commenced in 2011. With this, the poor segment of the population as well as the people whose religious and/or moral values do not encourage interest earnings or charges are inspired to open accounts with banks. The CBN has also intensified the regulation of e-banking products, electronic payment system and Cashless policy, which have culminated in the aggressive deployment of Automated Teller Machines (ATM's) and Point-of-Sale (PoS) Terminals. For instance, Nigeria has about 11 ATM's per 100,000 adults as against 59 per 100,000 adults in South Africa and 13 Points of Sale Terminals per 100,000 adults as against 1,067 per 100,000 adults in South Africa (Kama \& Adigun, 2013). 


\subsection{Proportion of Financially Included/Excluded Adult Population in Nigeria}

The proportion of banked adult population has consistently increased between 2008 and 2016. It increased from $18.3 \%$ in 2008 to $25.4 \%$ in $2010,28.6 \%$ in 2012 , then $33.9 \%$ and $36.9 \%$ in 2014 and 2016 respectively. The percentage of financially excluded adults decreased from $52.5 \%$ in 2008 to $46.3 \%$ in 2010 , then $39.7 \%$ and $39.5 \%$ in 2012 and 2014 respectively before rising to $41.6 \%$ in 2016 . The percentage of adult population included in the formal (other) has consistently increased from $2.5 \%$ in 2008 to $12.3 \%$ in in 2014 before dropping to $10.3 \%$ in 2016 . Meanwhile, the proportion of financially excluded adults consistently dropped from $52.5 \%$ in 2008 to $39.5 \%$ in 2014 before rising to $41.6 \%$ in 2016 (Table 3.1 and Figure 3.1).

Table 3.1: Distribution of Financially Included/Excluded Adult Population in Nigeria

\begin{tabular}{|l|l|l|l|l|l|l|l|l|}
\hline \multirow{2}{*}{ Year } & \multicolumn{3}{|c|}{ Banked } & \multicolumn{2}{c|}{ Formal (Other) } & \multicolumn{2}{l|}{ Informal Only } & \multicolumn{2}{l|}{$\begin{array}{l}\text { Financially } \\
\text { Excluded }\end{array}$} \\
\cline { 2 - 9 } & $\begin{array}{l}\text { Number } \\
\text { (Million) }\end{array}$ & $\%$ & $\begin{array}{l}\text { Number } \\
\text { (Million) }\end{array}$ & $\%$ & $\begin{array}{l}\text { Number } \\
\text { (Million) }\end{array}$ & $\%$ & $\begin{array}{l}\text { Number } \\
\text { (Million) }\end{array}$ & $\%$ \\
\hline 2008 & 18.3 & 21.1 & 2.2 & 2.5 & 20.7 & 23.9 & 45.4 & 52.5 \\
\hline 2010 & 25.4 & 30.0 & 5.3 & 6.3 & 14.8 & 17.4 & 39.2 & 46.3 \\
\hline 2012 & 28.6 & 32.5 & 9.2 & 10.5 & 15.2 & 17.3 & 34.9 & 39.7 \\
\hline 2014 & 33.9 & 36.3 & 11.5 & 12.3 & 11.3 & 11.9 & 36.9 & 39.5 \\
\hline 2016 & 36.9 & 38.3 & 10.0 & 10.3 & 9.4 & 9.8 & 40.1 & 41.6 \\
\hline
\end{tabular}

Source: EFInA Access to Financial Services in Nigeria Survey (2016)

\subsection{Implications of Strong Financial Inclusion for Sustainable Development in Nigeria}

The financial inclusion of the hitherto inadvertently excluded and the poor segments of the society would generate new economic activities and increase the scale of operations of existing firms thereby enabling them to harness new business opportunities and economies of scale. These would increase employment while private consumption would receive a boost. An increase in private consumption would encourage increase in investment which tends to further increase employment. Government, on the other hand, would beef up security, law and order as well as the provision of social services, which comes with an attendant increase in cost. When existing firms increase their scale of operations and new businesses come on board, and more jobs are created, government revenues through taxation increase, which it can also deploy to improve the wellbeing of the people. When employment increases (unemployment reduces), then poverty reduces. Increase in consumption, investment and government expenditures enhance economic growth and ultimately lead to poverty reduction. A consistent reduction in unemployment, poverty and inequality over a long period of time improves general wellbeing and the totality of all these imply sustainable development.

\subsection{Challenges Militating against Financial Inclusion in Nigeria}

Challenges militating against financial inclusion in Nigeria include:

Low Financial Literacy

Majority of Nigerians is characterized by low financial literacy, which makes it difficult for many potential customers to identify or harness banking opportunities.

\section{Cumbersome Banking Documentation and Minimum Operating Balance Requirements}

A lot of potential bank customers find account opening documentation very cumbersome and this discourages them from opening bank accounts. Another related issue is the minimum account balance requirements which may range from N1,000 - N50,000 depending on the account type. This is considered too high, especially for the poor segment of the population.

Inadequate and uneven distribution of Bank Branches and Alternative Banking Channels

Bank branches and alternative banking channels such as Automated Teller Machines (ATM's) and Point of Sale terminals are grossly inadequate and their distribution is asymmetrically skewed in favour central business districts, and urban centres mainly due to urban bias.

\section{Low Uptime and Malfunctioning of E-Channels}

Despite their inadequacy, the e-channels' uptime is low while cash or cards may be retracted on ATM's which discourage existing and potential bank Customers.

\section{Growing Poverty Incidence}

With an increasing poverty incidence which was estimated at about $71.5 \%$ (NBS, 2012), it implies that a high proportion of the population would be unbanked.

High Unemployment Rate

Nigeria's unemployment rate as at 2012 was estimated at 23.9\% (NBS, 2013). A vast majority of the unemployed people do not have any source of income neither do they enjoy any cash transfer which means they would not have anything to save in the bank. 
High Rural-Urban Migration

The high rate of rural-urban migration of able-bodied men and women depletes the market potential of the rural areas thereby discouraging the banks from opening branches there.

\section{Corruption}

Corruption has eaten deeply into the fabric of the Nigerian society. The high rate of corruption in the banking industry has led to the collapse of many banks thereby reducing the number of bank branches and financial inclusion capabilities.

\section{Intending Customers' Distrust of Financial Institutions}

Many potential customers have utter distrust for financial institutions, especially when the latter is about to benefit from the relationship. For instance, members of the public believe that banks do everything in order to mobilize deposits from them, but when it comes to the time for them to obtain overdrafts or loans, the former would then request that stringent conditions be met before they can enjoy such facilities.

\subsection{Conclusion and Recommendations}

The 2007/2008 global financial crisis lends credence to the pivot role played by the financial system. Financial inclusion is a veritable way for strengthening the financial system and generating inclusive growth with a view to achieving sustainable development in Nigeria. However, all hands must be on deck by major stakeholders towards accelerating financial inclusion in Nigeria by adopting the following strategies:

i. The Deposit Money Banks (DMB's) should join the Central Bank of Nigeria (CBN) enlightenment the public on how to keep accounts with formal financial institutions and the accruable benefits;

ii. The $\mathrm{CBN}$ should issue guidelines that minimizes banking documentation and reduces minimum operating balance;

iii. $\quad \mathrm{CBN}$ should re-introduce rural banking scheme in order to increase the presence of banks in the rural areas.

iv. DMB's should increase the rate of deployment /distribution of ATM's, PoS, and other alternative channels.

v. The DMB's and service providers should ensure increased uptime of e-channels.

vi. Financial education should be incorporated into the school curriculum.

vii. The three tiers of Government should step up their poverty alleviation initiatives.

viii. The Federal Government should create an enabling environment for enhanced investment, and increase employment generation.

ix. Government should ensure even distribution of infrastructure and development projects in order to minimize Rural-Urban Migration

x. Government should impose stiffer penalty against corruption and demonstrate strong political will to fight it.

xi. DMB's and other financial institutions should play by the rules and adhere to stipulated agreements with their customers in order to build mutual trust.

\section{References}

Ardic, O . P., Heimann, M. \& Nataliya, M. (2011). "Access to Financial Services and the Financial Inclusion Agenda around the world: A Cross-Country Analysis with a New Data Set."

Banco Central Do Brazil (2010). Report on Financial Inclusion. A Report of the Financial Inclusion Project in Brazil.

Banks and Other Financial Institutions Act (BOFIA) (1991).

Central Bank of Nigeria [CBN] Annual Reports and Statements of Accounts 1981-1983. Abuja: Central Bank of Nigeria.

Central Bank of Nigeria [CBN] (2011a): Questions and Answers on the CBN Policy on Cash

Withdrawal/ Lodgement Limits. A Paper Presented at a stakeholder Forum and hoisted on the CBN website at www.cenbank.org.

Central Bank of Nigeria [CBN] (2011b). Microfinance Policy Framework for Nigeria (Revised).

Abuja: Central Bank of Nigeria.

Central Bank of Nigeria (2017). The Nigerian Financial System at a Glance. Abuja: Central Bank of Nigeria.

Central Bank of Nigeria [CBN] (2018). Report on Financial Inclusion https://www.cbn.gov.ng/devfin/fininc.asp on 15 th July, 2018

CGAP, World Bank (2010). "Financial Access 2010: The State of Financial Inclusion through the Crisis", http://www.microrate.com/financial-acces.

Enhancing Financial Innovation and Access [EFInA] (2008). Access to Financial Services in Nigeria Survey. EFInA.

Enhancing Financial Innovation and Access [EFInA] (2016). Access to Financial Services in Nigeria Survey. 
EFInA.

Kama \& Adigun (2013). Financial Inclusion in Nigeria: Issues and Challenges. Occassional Paper No. 45. Abuja: Central Bank of Nigeria.

Mohan, R. (2006). Economic Growth, Financial Deepening and Financial Inclusion. Address of the Annual Bankers Conference at Hyderabad on November, 3.

National Bureau of Statistics [NBS] (2012). Nigeria Poverty Profile. Abuja. NBS. Available at http://www.nigerianstat.gov.ng/uploads/latestRelease

National Bureau of Statistics, NBS (2013). National Baseline Youth Survey Report for 2012.Abuja: NBS Available at http://www.nigerianstat.gov.ng/uploads/latestRelease

Plymouth City Council (2009). Financial Inclusion: A Multi-Agency Strategy for Plymouth, April, 2009 to March, 2012

Sanusi, L.S. (2011). "Financial Inclusion for Accelerated Micro, Small and Medium Enterprises

Development: The Nigerian Perspective" Paper Presented at the 2011 Annual Microfinance and Entrepreneurship Awards.

Seers, D. (1969). The Meaning of Development. IDS Communication 44, Institute of Development Studies.

United Nations (2016). The Sustainable Development Report. New York: United Nations.

World Commission on Environment and Development [Brundtland Commission] (1997). Our Common Future. New York: Oxford University Press. 